\title{
Reclassification of Lactobacillus catenaformis (Eggerth 1935) Moore and Holdeman 1970 and Lactobacillus vitulinus Sharpe et al. 1973 as Eggerthia catenaformis gen. nov., comb. nov. and Kandleria vitulina gen. nov., comb. nov., respectively
}

\author{
Elisa Salvetti, ${ }^{1}$ Giovanna E. Felis, ${ }^{1}$ Franco Dellaglio, ${ }^{1}$ Anna Castioni, ${ }^{1 \dagger}$ \\ Sandra Torriani ${ }^{1}$ and Paul A. Lawson ${ }^{2}$ \\ ${ }^{1}$ Department of Biotechnology, University of Verona, Strada le Grazie 15, 37134 Verona, Italy \\ ${ }^{2}$ Department of Botany and Microbiology, University of Oklahoma, Norman, OK 73019, USA
}

Correspondence Giovanna E. Felis giovanna.felis@univr.it

\begin{abstract}
The development of molecular tools and in particular the use of 16S rRNA gene sequencing has had a profound effect on the taxonomy of many bacterial groups. Gram-positive organisms that encompass the genera Lactobacillus and Clostridium within the Firmicutes are examples of taxa that have undergone major revisions based on phylogenetic information. A consequence of these reorganizations is that a number of organisms are now recognized as being misclassified. Previous studies have demonstrated that Lactobacillus catenaformis and Lactobacillus vitulinus are phylogenetically unrelated to Lactobacillus sensu stricto, being placed within the Clostridia rRNA cluster XVII. Based on the phenotypic, chemotaxonomic and phylogenetic data presented, it is proposed that $L$. catenaformis and $L$. vitulinus be reclassified in two new genera, named respectively Eggerthia gen. nov., with the type species Eggerthia catenaformis gen. nov., comb. nov. (type strain DSM $20559^{\top}=$ ATCC $25536^{\top}=$ CCUG $48174^{\top}=$ CIP $104817^{\top}=$ JCM $1121^{\top}$ ) and Kandleria gen. nov., with the type species Kandleria vitulina gen. nov., comb. nov. (type strain LMG $18931^{\top}=$ ATCC $27783^{\top}=$ CCUG $32236^{\top}=$ DSM $20405^{\top}=$ JCM $1143^{\top}$ ).
\end{abstract}

The genus Lactobacillus and the genera Paralactobacillus and Pediococcus belong to the family Lactobacillaceae, which is a member of the order 'Lactobacillales', a major phylogenetic group of the Firmicutes. Numerous studies using 16S rRNA gene sequencing have demonstrated that the species Lactobacillus catenaformis and Lactobacillus vitulinus are phylogenetically unrelated to Lactobacillus sensu stricto (Collins et al., 1991; Pot et al., 1994; Schleifer \& Ludwig, 1995). Furthermore, Collins and co-workers demonstrated that these species were phylogenetically placed within the Clostridia rRNA cluster XVII. Recently, two novel genera have been described, namely Catenibacterium (Kageyama \& Benno, 2000) and Sharpea (Morita et al., 2008) and were phylogenetically located in cluster XVII of the clostridia. In particular, in the latest edition of the Bergey's Manual of Systematic Bacteriology (available online at http://www. bergeys.org/outlines.html), Catenibacterium mitsuokai is

tPresent address: Yakult Italia, Via V. Monti, 51, 20123 Milan, Italy.

The GenBank/EMBL/DDBJ accession number for the 16S rRNA gene sequence of Lactobacillus catenaformis DSM $20559^{\top}$ is AJ621549.

A supplementary table is available with the online version of this paper. placed within the family Erysipelotrichaceae together with other species described as members of genera not assigned to this family, including $L$. catenaformis and $L$. vitulinus. Furthermore, it has also been suggested that L. catenaformis and $L$. vitulinus be included in this phylogenetic grouping (Stackebrandt, 2009).

Based on our present study and the observations of others, $L$. catenaformis and L. vitulinus are discussed with respect to their taxonomic status and their reclassification as Eggerthia gen. nov., with the type species Eggerthia catenaformis gen. nov., comb. nov. and Kandleria gen. nov. with the type species Kandleria vitulina gen. nov., comb. nov. is proposed.

The 16S rRNA gene sequence of $L$. catenaformis DSM $20559^{\mathrm{T}}$ located in EMBL/GenBank was submitted in 1989, and contained a number of sequencing ambiguities originating from the reverse transcriptase sequencing method used. To ensure as accurate results as possible, this strain was resequenced using present day methods incorporating direct sequencing of the 16S rRNA gene PCR product. The most recent published sequence of 
L. vitulinus was from a recent study (Morita et al., 2008) and was therefore used in the present study. L. catenaformis DSM $20559^{\mathrm{T}}$ was grown in an optimized peptone medium and in MRS $+0.5 \mathrm{~g} \mathrm{Cys-HCl} \mathrm{l}^{-1}$, respectively, both at $37{ }^{\circ} \mathrm{C}$ in anaerobiosis. The composition of the peptone medium was the following $\left(1^{-1}\right): 20 \mathrm{~g}$ BHI broth, $15 \mathrm{~g}$ tryptone, $20 \mathrm{~g}$ phytone peptone, $20 \mathrm{~g}$ special peptone, $20 \mathrm{~g}$ Bacto peptone, $20 \mathrm{~g}$ meat extract, $20 \mathrm{~g}$ proteose peptone, 20 g peptone, 5 g yeast extract, $5 \mathrm{~g} \mathrm{~K}_{2} \mathrm{HPO}_{4}, 7.5 \mathrm{ml}$ freshly prepared yeast extract and $0.5 \mathrm{~g}$ Cys- $\mathrm{HCl}$.

The partial 16S rRNA gene sequence for $L$. catenaformis DSM $20559^{\mathrm{T}}$ was obtained using primers Lac16S-for $\left(5^{\prime}\right.$ AATGAGAGTTTGATCCTGGCT- ${ }^{\prime}$ ) and Lac16S-rev (5' GAGGTGATCCAGCCGCAGGTT- $3^{\prime}$ ). The reaction mixture $(20 \mu \mathrm{l})$ contained $30 \mathrm{ng}$ template DNA, $1.5 \mathrm{mM}$ $\mathrm{MgCl}_{2}, 0.2 \mathrm{mM}$ dNTPs, $1 \mu \mathrm{M}$ each primer and $1 \mathrm{U}$ Taq DNA polymerase (Polymed) in a standard reaction buffer. After an initial denaturation of $4 \mathrm{~min}$ at $94{ }^{\circ} \mathrm{C}$, 25 cycles of $1 \mathrm{~min}$ at $94{ }^{\circ} \mathrm{C}, 1.5 \mathrm{~min}$ at $50{ }^{\circ} \mathrm{C}, 2 \mathrm{~min}$ at $72{ }^{\circ} \mathrm{C}$ and a final extension at $72{ }^{\circ} \mathrm{C}$ for 7 min were performed. The $1.6 \mathrm{~kb}$ amplification product was extracted from the agarose gel (Promega elution kit) and sequenced at the Biomolecular Research (BMR) Center at Padua University (Italy). The cells harvested were checked for purity and DNA was extracted by the procedure of Marmur (1961).

To establish the closest relatives, 16S rRNA gene sequences were used to check the phylogenetic placement of the two species as obtained by online resources such as BLASTN (http://blast.ncbi.nlm.nih.gov/Blast.cgi) and SEQMATCH (http: //rdp.cme.msu.edu/index.jsp). BLAST searches and SEQMATCH analyses showed a relationship between the $L$. catenaformis DSM $20559^{\mathrm{T}}$ and L. vitulinus LMG $18931^{\mathrm{T}}$ sequences and those of Sharpea azabuensis ST18 ${ }^{\mathrm{T}}$ and Catenibacterium mitsuokai JCM $10609^{\mathrm{T}}$, respectively, which are included in Clostridium subphylum cluster XVII.

16S rRNA gene sequences of the type species of family Lactobacillaceae, L. catenaformis, L. vitulinus, S. azabuensis and Catenibacterium mitsuokai, as well as other related organisms of the family Erysipelothricaceae, which belong to other Clostridium clusters, were aligned. Unknown bases were disregarded and 1320 positions were included in a phylogenetic analysis. Phylogenetic trees were constructed using the Jukes and Cantor method as the distance formula and the neighbour-joining (Saitou \& Nei, 1987) and minimum evolution (Nei \& Kumar, 2000) methods as suggested by Kämpfer and co-workers (Kämpfer et al., 2003) as implemented in the MEGA v4 software package (Tamura et al., 2007). The statistical reliability of the topology of the phylogenetic trees was evaluated using bootstrapping with 1000 replicates (Felsenstein, 1985). All the major branching nodes were confirmed by maximumparsimony analysis (data not shown).

Phylogenetic analyses employing 16S rRNA gene sequences showed that the species of the family Lactobacillaceae included in the analysis formed a separate clade while both $L$. catenaformis and $L$. vitulinus were placed within the Clostridium subphylum cluster XVII, related to S. azabuensis and Catenibacterium mitsuokai, respectively (Fig. 1).

Although this placement is within clostridia-like organisms, phylogenetic studies based on the 16S rRNA gene have been used by a number of authors to show the need for a revision of the genus Clostridium (Lawson et al., 1993; Stackebrandt et al., 1999; Wiegel et al., 2006). Indeed, Collins et al. (1994) proposed a possible hierarchical framework for future classification of clostridia with a proposal to restrict the

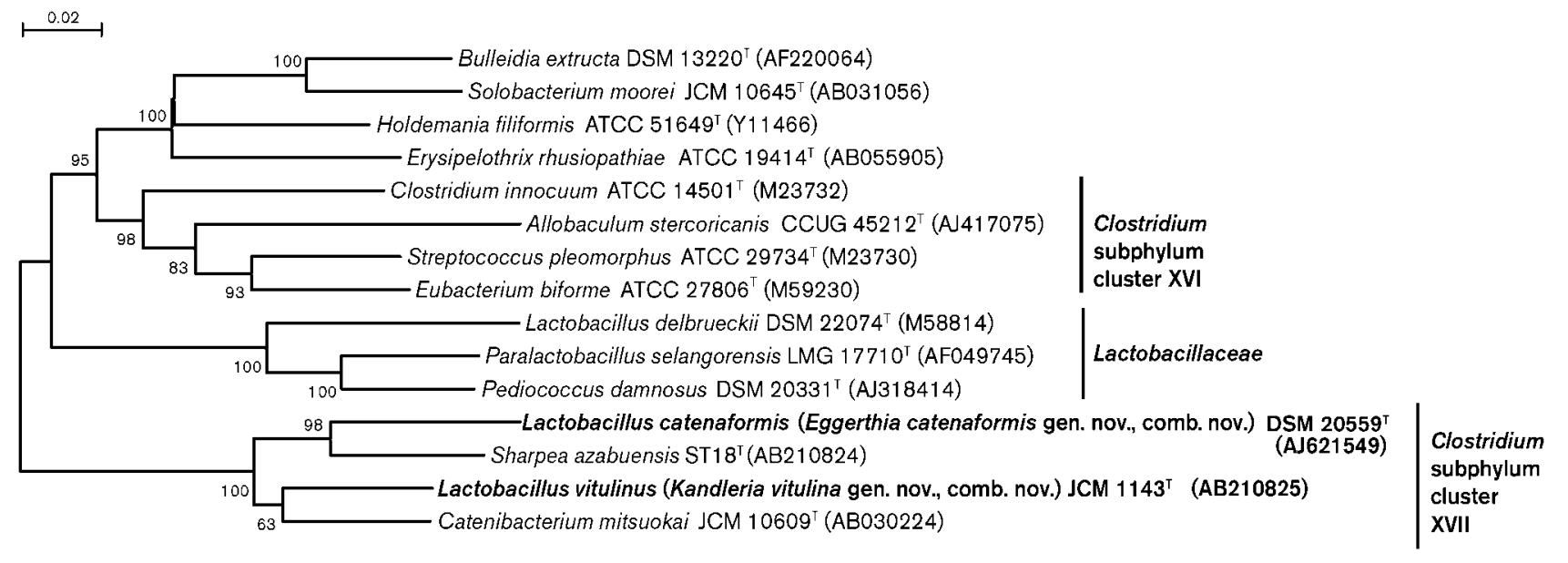

Fig. 1. The phylogenetic relationship of Kandleria vitulina gen. nov., comb. nov. and Eggerthia catenaformis gen. nov., comb. nov. with respect to representative species of the Lactobacillaceae based on the 16S rRNA gene sequences. The tree was constructed using Jukes and Cantor's method and the minimum evolution algorithm. Bootstrap values (1000 replicates) are reported in percentage at nodes (only values higher than $60 \%$ are represented). Bar, 0.02 nucleotide substitutions. 
genus Clostridium to organisms that formed a distinct cluster in the $16 \mathrm{~S}$ rRNA tree (cluster I) and that these should be regarded as the true representatives of the genus Clostridium (i.e. Clostridium sensu stricto).

The phylogenetic analysis undertaken in this study confirmed previous findings that $L$. catenaformis and $L$. vitulinus formed a loose association with $S$. azabuensis and Catenibacterium mitsuokai respectively. Pairwise sequence alignments revealed that $L$. vitulinus showed low sequence similarities with Catenibacterium mitsuokai (91.2\%), L. catenaformis (87.1\%), and S. azabuensis (90.6). Similarly, $L$. catenaformis showed equally low values with Catenibacterium mitsuokai (84.8\%), and S. azabuensis $(88.9 \%)$. These phylogenetic depths (almost higher than $10 \%$ ) of $L$. catenaformis and $L$. vitulinus with their respective nearest relatives suggest that each of these misplaced lactobacilli forms the nucleus of a novel genus. The separateness of these organisms was supported by low DNA-DNA hybridization values (Morita et al., 2008) (see Supplementary Table S1 in IJSEM Online) in addition to phenotypic and chemotaxonomic information (Table 1).

However, it is clear that this cluster of organisms share many similar traits with only a few of them useful as diagnostic markers. Thus an accurate identification, especially at the laboratory bench, is becoming ever more reliant on rapid molecular genetic techniques such as $16 \mathrm{~S}$ rRNA gene sequence comparisons. These high throughput methodologies are becoming increasingly automated and the costs are declining, making them accessible to the routine laboratory or available as services offered by commercial facilities. These methods allow accurate identification of hitherto unknown taxa with a turnaround time of only a matter of hours or days. It is becoming increasingly common for isolates to be identified by $16 \mathrm{~S}$ rRNA gene sequencing first before biochemical and chemotaxonomic analyses are undertaken. Such changes are reflected in the latest edition of Bergey's Manual of Systematic Bacteriology where the format now follows a phylogenetic basis for the classification of micro-organisms and many examples exist of organisms being grouped on phylogenetic information but which possess few differential phenotypic traits (Rainey, 2009).

Based on phenotypic, chemotaxonomic and phylogenetic evidence that demonstrates their separateness from the genus Lactobacillus and placement in family Erysipelotrichaceae (Clostridium subphylum cluster XVII) within the class Erysipelotrichia, we consider that the species $L$. catenaformis and L. vitulinus merit classification in two new genera, for which the names Eggerthia gen. nov., and Kandleria gen. nov. are proposed, respectively.

Table 1. Physiological characteristics of Catenibacterium mitsuokai, L. catenaformis, L. vitulinus and S. azabuensis

Taxa: 1, Catenibacterium mitsuokai JCM $10609^{\mathrm{T}} ; 2$, L. catenaformis JCM $1121^{\mathrm{T}} ; 3$, L. vitulinus JCM $1143^{\mathrm{T}} ; 4$, S. azabuensis ST18 ${ }^{\mathrm{T}}$. + , Positive; -, negative; ND, no data available; Dpm, diaminopimelic acid; A, acetate; L, lactate; B, butyrate; F, formate; IB, iso-butyrate. Upper case letters represent a major product, lower case letters represent minor products. Values in parentheses show end products present only in some strains. All strains were positive for the fermentation of glucose, galactose, fructose, mannose, cellobiose and lactose. All strains were negative for aerobic growth, growth at $15{ }^{\circ} \mathrm{C}$, catalase activity and fermentation of rhamnose, mannitol, sorbitol and melezitose. Data from Sharpe et al., 1973; Moore \& Holdeman, 1970; Kageyama \& Benno, 2000 and Morita et al., 2008.

\begin{tabular}{|c|c|c|c|c|}
\hline Characteristic & 1 & 2 & 3 & 4 \\
\hline Metabolic end products* & $A, L, B, i b$ & $\mathrm{~L}, \mathrm{a},(\mathrm{f})$ & $\mathrm{L}, \mathrm{a}$ & $\mathrm{L}$ \\
\hline Lactic acid isomer(s) & DL & $\mathrm{D}$ & $\mathrm{D}$ & $\mathrm{D}$ \\
\hline Fermentation style $\dagger$ & $\mathrm{HO}$ & $\mathrm{HO}$ & $\mathrm{HO}$ & $\mathrm{HE}$ \\
\hline \multicolumn{5}{|l|}{ Fermentation of: } \\
\hline Salicin & + & + & + & - \\
\hline Melibiose & ND & - & + & + \\
\hline Trehalose & - & - & - & - \\
\hline Raffinose & - & - & - & - \\
\hline Starch & - & + & + & + \\
\hline D-Xylose & - & + & - & - \\
\hline D-Arabinose & - & + & - & - \\
\hline D-Ribose & - & + & - & - \\
\hline DNA $\mathrm{G}+\mathrm{C}$ content $(\mathrm{mol} \%)$ & 36.6 & 34.8 & 34.4 & 37.4 \\
\hline Cell wall murein & $\begin{array}{c}\mathrm{A} 1 \gamma(\mathrm{L}-\mathrm{Ala})-\mathrm{D}- \\
\text { Glu-m-Dpm }\end{array}$ & A3 $\alpha$ L-Lys-L-Ala 3 & Al $\gamma$ m-Dpm-direct & $\begin{array}{r}\text { A1 } \gamma(\mathrm{L}-\mathrm{Ala})-\mathrm{D}- \\
\text { Glu- } m-\mathrm{Dpm}\end{array}$ \\
\hline Source & Human faeces & $\begin{array}{c}\text { Human faeces, intestinal and pleural } \\
\text { infections }\end{array}$ & Bovine rumen & Horse faeces \\
\hline
\end{tabular}

${ }^{\star}$ From glucose.

$\dagger$ HE, heterofermentative; HO, homofermentative. 


\section{Description of Eggerthia gen. nov.}

Eggerthia (Eg.ger'thi.a. N.L. fem. n. Eggerthia named after Arnold H. Eggerth, who first identified the species Lactobacillus catenaformis).

Cells are Gram-positive, non-spore-bearing anaerobic rods that often occur in short chains. Lactic acid is the main product from glucose. The cell wall contains the Lys-Ala peptidoglycan type and the $\mathrm{G}+\mathrm{C}$ content of the DNA is $31-33 \mathrm{~mol} \%$. The genus Eggerthia is a member of the family Erysipelotrichaceae (Clostridium subphylum cluster XVII) and exhibits a close phylogenetic association with Catenibacterium mitsuokai, L. vitulinus (to be reclassified as Kandleria vitulina gen. nov., comb, nov., see below) and $S$. azabuensis. The type species is Eggerthia catenaformis.

\section{Description of Eggerthia catenaformis comb. nov.}

Eggerthia catenaformis [ca.te.na.for'mis. L. n. catena chain; L. suff. -formis (from L. n. forma figure, shape, appearance) -like, in the shape of; N.L. fem. adj. catenaformis chainshaped].

Basonym: Lactobacillus catenaformis corrig. (Eggerth 1935) Moore and Holdeman 1970.

Displays the following properties in addition to those described for the genus. Cells are small, slightly irregular rods and occur often in chains. Catalase-negative and nonmotile. Good growth occurs at $37-45{ }^{\circ} \mathrm{C}$. Negative in tests for arginine dihydrolase. Acid is produced from galactose, glucose, fructose, mannose, cellobiose, lactose, sucrose, starch, amygdalin, aesculin and salicin. Acid is not produced from arabinose, ribose, xylose, rhamnose, trehalose, melibiose, melezitose, raffinose, mannitol or sorbitol. The type strain metabolizes glucose homofermentatively to produce $(-)$-D-lactic acid. No gas is produced from glucose. The structure of the cell-wall murein is L-Lys-L-Ala $3(\mathrm{~A} 3 \alpha)$.

The type strain is DSM $20559^{\mathrm{T}}\left(=\right.$ ATCC $25536^{\mathrm{T}}=$ CCUG $48174^{\mathrm{T}}=$ CIP $104817^{\mathrm{T}}=$ JCM $\left.1121^{\mathrm{T}}\right)$. Strains of this species have been isolated from human faeces and intestinal and pleural infections.

\section{Description of Kandleria gen. nov.}

Kandleria (Kand.le' ri.a. N.L. fem. n. Kandleria named after Otto Kandler, for his outstanding contribution to the study of lactic acid bacteria and for the first identification of Lactobacillus vitulinus).

Cells are Gram-positive, non-spore-forming, anaerobic rods. The cell wall contains peptidoglycan of the D-mesodiaminopimelic acid type and $\mathrm{G}+\mathrm{C}$ content of the DNA is $34-37 \mathrm{~mol} \%$. The genus Kandleria is a member of the family Erysipelotrichaceae (Clostridium subphylum cluster XVII) and exhibits a close phylogenetic association with Catenibacterium mitsuokai, Eggerthia catenaformis and S. azabuensis. The type species is Kandleria vitulina.

\section{Description of Kandleria vitulina comb. nov.}

Kandleria vitulina (vi.tu.li'na. L. fem. adj. vitulina of a calf).

Basonym: Lactobacillus vitulinus Sharpe et al. 1973.

Displays the following properties in addition to those described for the genus. Cells are rod-shaped with rounded ends $(0.5-0.7 \times 2.4 \mu \mathrm{m})$ and occur singly and in pairs. Catalase-negative and non-motile. Good growth in freshly boiled MRS broth supplemented with $0.05 \%(w / v)$ cysteine- $\mathrm{HCl}$. Grows at $45{ }^{\circ} \mathrm{C}$, but not at $15{ }^{\circ} \mathrm{C}$. Arginine is not hydrolysed. Acid is produced from galactose, glucose, fructose, mannose, cellobiose, maltose, lactose, sucrose, melibiose, starch, amygdalin, aesculin and salicin. Acid is not produced from arabinose, ribose, xylose, rhamnose, trehalose, melezitose, raffinose, mannitol or sorbitol. The type strain metabolizes glucose homofermentatively producing (-)-D-lactic acid. No gas is produced from glucose. The peptidoglycan type is meso-diaminopimelic acid.

The type strain, LMG $18931^{\mathrm{T}}\left(=\right.$ ATCC $27783^{\mathrm{T}}=$ CCUG $32236^{\mathrm{T}}=$ DSM $20405^{\mathrm{T}}=$ JCM $1143^{\mathrm{T}}$ ), was isolated from the rumen of a six-week-old calf. Members of this species have also been isolated from bovine rumen.

\section{References}

Collins, M. D., Rodrigues, U., Ash, C., Aguirre, M., Farrow, J. A. E., Martinez-Murcia, A., Phillips, B. A., Williams, A. M. \& Wallbanks, S. (1991). Phylogenetic analysis of the genus Lactobacillus and related lactic acid bacteria as determined by reverse transcriptase sequencing of 16S rRNA. FEMS Microbiol Lett 77, 5-12.

Collins, M. D., Lawson, P. A., Willems, A., Cordoba, J. J., FernandezGarayzabal, J., Garcia, P., Cai, J., Hippe, H. \& Farrow, J. A. E. (1994). The phylogeny of the genus Clostridium: proposal of five new genera and eleven new species combinations. Int J Syst Bacteriol 44, 812826.

Eggerth, A. H. (1935). The Gram-positive non-spore-bearing anaerobic bacilli of human feces. J Bacteriol 30, 277-299.

Felsenstein, J. (1985). Confidence limits on phylogenies: an approach using the bootstrap. Evolution 39, 783-791.

Kageyama, A. \& Benno, Y. (2000). Catenibacterium mitsuokai gen. nov., sp. nov., a gram-positive anaerobic bacterium isolated from human faeces. Int J Syst Evol Microbiol 50, 1595-1599.

Kämpfer, P., Buczolits, S., Albrecht, A., Busse, H.-J. \& Stackebrandt, E. (2003). Towards a standardized format for the description of a novel species (of an established genus): Ochrobactrum gallinifaecis sp. nov. Int J Syst Evol Microbiol 53, 893-896.

Lawson, P. A., Llop-Perez, P., Hutson, R. A., Hippe, H. \& Collins, M. D. (1993). Towards a phylogeny of the clostridia based on $16 \mathrm{~S}$ rRNA sequences. FEMS Microbiol Lett 113, 87-92.

Marmur, J. (1961). A procedure for the isolation of deoxyribonucleic acid from microorganisms. J Mol Biol 3, 208-218.

Moore, W. E. C. \& Holdeman, L. V. (1970). Propionibacterium, Arachnia, Actinomyces, Lactobacillus and Bifidobacterium. In Outline of Clinical Methods in Anaerobic Bacteriology, 2nd revision, pp. 15-22. Edited by E. P. Cato, C. S. Cummins, L. V. Holdeman, J. L. Johnson, W. E. C. Moore, R. M. Smibert \& L. D. S. Smith. Blacksburg, Virginia, USA: Anaerobe Laboratory, Virginia Polytechnic Institute. 
Morita, H., Shiratori, C., Murakami, M., Takami, H., Toh, H., Kato, Y., Nakajima, F., Takagi, M., Akita, H. \& other authors (2008). Sharpea azabuensis gen. nov., sp. nov., a Gram-positive, strictly anaerobic bacterium isolated from the faeces of thoroughbred horses. Int J Syst Evol Microbiol 58, 2682-2686.

Nei, M. \& Kumar, S. (2000). Molecular Evolution and Phylogenetics. New York: Oxford University Press.

Pot, B., Ludwig, W., Kersters, K. \& Schleifer, K.-H. (1994). Taxonomy of lactic acid bacteria. In Bacteriocins of Lactic Acid Bacteria: Microbiology, Genetics and Applications, pp. 13-90. Edited by L. de Vuyst \& E. J. Vandamme. UK: Blackie Academic \& Professional.

Rainey, F. A. (2009). Family V. Lachnospiraceae fam. nov. In Bergey's Manual of Systematic Bacteriology, 2nd edn, vol. 3, pp. 921-968. Edited by P. De Vos, G. M. Garrity, D. Jones, N. R. Krieg, W. Ludwig, F. A. Rainey, K.-H. Schleifer \& W. B. Whitman. New York: Springer.

Saitou, N. \& Nei, M. (1987). The neighbor-joining method: a new method for reconstructing phylogenetic trees. Mol Biol Evol 4, 406425.

Schleifer, K. H. \& Ludwig, W. (1995). Phylogenetic relationships of lactic acid bacteria. In The Genera of Lactic Acid Bacteria, pp. 7-18.
Edited by B. J. B. Wood \& W. H. Holzapfel. London: Blackie Academic \& Professional.

Sharpe, M. E., Latham, M. J., Garvie, E. I., Zirngibl, J. \& Kandler, O. (1973). Two new species of Lactobacillus isolated from the bovine rumen, Lactobacillus ruminis sp. nov. and Lactobacillus vitulinus sp. nov. J Gen Microbiol 77, 37-49.

Stackebrandt, E. (2009). Family 1. Erysipelotrichaceae. In Bergey's Manual of Systematic Bacteriology, 2nd edn, vol. 3, pp. 1299-1317. Edited by P. De Vos, G. M. Garrity, D. Jones, N. R. Krieg, W. Ludwig, F. A. Rainey, K.-H. Schleifer \& W. B. Whitman. New York: Springer.

Stackebrandt, E., Kramer, I., Swiderski, J. \& Hippe, H. (1999). Phylogenetic basis for a taxonomic dissection of the genus Clostridium. FEMS Immunol Med Microbiol 24, 253-258.

Tamura, K., Dudley, J., Nei, M. \& Kumar, S. (2007). MEGA4: molecular evolutionary genetics analysis (MEGA) software version 4.0. Mol Biol Evol 24, 1596-1599.

Wiegel, J., Tanner, R. \& Rainey, F. A. (2006). An introduction to the family Clostridiaceae. In The Prokaryotes: a Handbook on the Biology of Bacteria, 3rd edn, vol. 4, pp. 654-678. Edited by M. Dworkin, S. Falkow, E. Rosenberg, K. H. Schleifer \& E. Stackebrandt. New York: Springer. 